\title{
Efficient inverted tandem polymer solar cells with a solution- processed recombination layer
}

\section{Citation for published version (APA):}

Kouijzer, S., Esiner, S., Frijters, C. H. M., Turbiez, M. G. R., Wienk, M. M., \& Janssen, R. A. J. (2012). Efficient inverted tandem polymer solar cells with a solution-processed recombination layer. Advanced Energy Materials, 2(8), 945-949. https://doi.org/10.1002/aenm.201100773

DOI:

10.1002/aenm.201100773

Document status and date:

Published: 01/01/2012

\section{Document Version:}

Accepted manuscript including changes made at the peer-review stage

\section{Please check the document version of this publication:}

- A submitted manuscript is the version of the article upon submission and before peer-review. There can be important differences between the submitted version and the official published version of record. People interested in the research are advised to contact the author for the final version of the publication, or visit the $\mathrm{DOI}$ to the publisher's website.

- The final author version and the galley proof are versions of the publication after peer review.

- The final published version features the final layout of the paper including the volume, issue and page numbers.

Link to publication

\section{General rights}

Copyright and moral rights for the publications made accessible in the public portal are retained by the authors and/or other copyright owners and it is a condition of accessing publications that users recognise and abide by the legal requirements associated with these rights.

- Users may download and print one copy of any publication from the public portal for the purpose of private study or research.

- You may not further distribute the material or use it for any profit-making activity or commercial gain

- You may freely distribute the URL identifying the publication in the public portal.

If the publication is distributed under the terms of Article 25fa of the Dutch Copyright Act, indicated by the "Taverne" license above, please follow below link for the End User Agreement:

www.tue.nl/taverne

Take down policy

If you believe that this document breaches copyright please contact us at:

openaccess@tue.nl

providing details and we will investigate your claim. 


\title{
Efficient Inverted Tandem Polymer Solar Cells with a Solution-Processed Recombination Layer
}

\author{
Sandra Kouijzer, Serkan Esiner, Corné H. Frijters, Mathieu Turbiez, Martijn M. Wienk, \\ and René A. J. Janssen*
}

By developing new photoactive materials and advanced processing procedures the power conversion efficiency of polymer-fullerene bulk heterojunction solar cells has increased significantly and now approaches $10 \% \cdot{ }^{[1-3]}$ The efficiency of polymer solar cells can be further improved by using a tandem configuration. Compared to single-junction cells, tandem cells reduce thermalization losses by absorbing high-energy photons in a wide band gap cell, and reduce transmission losses by absorbing low-energy photons in a small band gap cell. The choice of materials used in the two photoactive layers and in the recombination layer that serves to electrically connect the two subcells are crucial for the performance of a tandem cell. The photoactive layers must provide high conversion efficiencies, whereas the recombination interlayer should provide a contact with minimal resistive, optical, and energetic losses.

The development of polymer tandems cells is receiving increasing attention. ${ }^{[4-9]}$ Most tandem cells reported so far, have the traditional polarity configuration, that is, with a transparent hole collecting contact and an opaque metallic electron collecting contact. However, inverted configurations with a metallic hole-collecting contact and transparent electron-collecting contact ${ }^{[10,11]}$ may have an advantage with respect to printability and stability due to the relative environmental stability of the electron transport layer and hole-collecting contact. ${ }^{[12,13]}$

The first inverted tandem solar cells were reported by Sun and co-workers ${ }^{[14,15]}$ who used poly(3-hexylthiophene):[6,6]phenyl- $\mathrm{C}_{61}$-butyric acid methyl ester (P3HT:[60]PCBM) bulk heterojunction solar cells in both layers of the tandem. The intermediate recombination contact used was a complex stack of thermally evaporated $\mathrm{MoO}_{3}$ and ultrathin multiple metal layers of $\mathrm{Ag}, \mathrm{Al}$, and $\mathrm{Ca}$. This recombination contact provided an exact summation of the open-circuit voltage $\left(V_{\text {oc }}\right)$ of the subcells and a power conversion efficiency of $\eta=2.8 \%$. Improved efficiencies for inverted tandem polymer solar cells were reported by Yang and co-workers. ${ }^{[16]}$ By using a wide-band P3HT:[60]PCBM front cell and a small band gap poly(4,4-dioctyldithieno(3,2b:2', 3'-d) silole)-2,6-diyl-alt-(2,1,3-benzothiadiazole)-4,7diyl):[6,6]phenyl-C $\mathrm{C}_{71}$-butyric acid methyl ester (PSBTBT:[70]

S. Kouijzer, S. Esiner, C. H. Frijters, Dr. M. M. Wienk, Prof. R. A. J. Janssen

Molecular Materials and Nanosystems

Eindhoven University of Technology

PO Box 513, 5600 MB Eindhoven, The Netherlands

E-mail: r.a.j.janssen@tue.nl

Dr. M. Turbiez

BASF Schweiz AG, Schwarzwaldallee 215, CH-4002 Basel, Switzerland

DOI: 10.1002/aenm.201100773
PCBM back) cell an efficiency of $\eta=5.1 \%$ was obtained. ${ }^{[16]}$ For the recombination contact, $\mathrm{MoO}_{3}$ and $\mathrm{Al}$ were thermally evaporated, followed by depositing $\mathrm{ZnO}$ using a precursor solution. Jen and co-workers ${ }^{[17]}$ reported the first solution-processed inverted tandem polymer solar cell using a PEDOT:PSS/ZnO recombination contact between two P3HT:[60]PCBM photoactive layers. They demonstrated that cells can be improved using a fullerene self-assembled $\left(\mathrm{C}_{60}\right.$-SAM) to modify the interface between the $\mathrm{ZnO}$ and the P3HT:[60]PCBM layer. The highest tandem cell reported had $\eta=2.9 \%$, but actually performed less than the best single-junction cell $(\eta=4.1 \%)$ presented in the same study. ${ }^{[17]}$ More recently, Krebs and co-workers reported another fully solution-processed inverted polymer tandem solar cell with a P3HT:[60]PCBM front cell and a back cell consisting of poly(dithienothiophene-co-dialkoxybenzothiadiazole) (PDTTDABT) with [60]PCBM. ${ }^{[18]}$ The recombination layer consisted of $\mathrm{V}_{2} \mathrm{O}_{5} / \mathrm{Ag}$ nanoparticles/ZnO. The inverted tandem showed an efficiency of $\eta=1.0 \%$ and a loss in $V_{\text {oc }}$ compared to summed $V_{\text {oc }}$ of the single-junction solar cells.

In all inverted polymer tandem solar cells reported to date the $V_{\text {oc }} \mathrm{S}$ of the two subcells are virtually identical. Hence, neither of these inverted tandem cells really exploits the fundamental advantage of a tandem configuration, where high-energy photons should be converted in a wide band gap subcell with a higher $V_{\text {oc }}$ and the low-energy photons in a small band gap cell with lower $V_{\text {oc }}$. Only in this way, thermalization and transmission losses can both be reduced simultaneously. Further, to enable future rollto-roll processing of efficient inverted tandem cells, there is an obvious need for robust solution-processed recombination layers.

Here we demonstrate an efficient inverted tandem polymer solar cell configuration (Figure 1a) that overcomes both problems. We develop a fully solution-processed PEDOT:PSS/ZnO recombination layer that connects the two subcells with minimal losses. The inverted tandem cell uses a wide band gap bulk heterojunction front cell consisting of P3HT as donor and indene$\mathrm{C}_{60}$-bisadduct (ICBA) ${ }^{[19]}$ as acceptor (Figure 1b). P3HT:ICBA cells give efficient solar cells with $V_{\text {oc }}=0.84 \mathrm{~V}$ in a conventional configuration. ${ }^{[20]}$ The small band gap back cell of our tandem consists of a diketopyrrolopyrrole-quinquethiophene copolymer (PDPP5T, Figure 1b) as donor with [60]PCBM as acceptor, which provides $V_{\text {oc }}=0.58 \mathrm{~V}$ in a standard device layout. ${ }^{[21]}$ With bandgaps of 1.87 and $1.46 \mathrm{eV}$, the optical absorption of the two active layers are complementary and cover a large part of the solar emission (Figure 1c). We show that the individual single-junction cells provide power conversion efficiencies of $\eta=4.4 \%$ and $\eta=5.0 \%$ in an inverted configuration and reach $\eta=5.8 \%$ when combined in an inverted tandem cell.

To create an inverted device polarity, it is necessary to modify the work function of the optically transparent bottom 
(a)

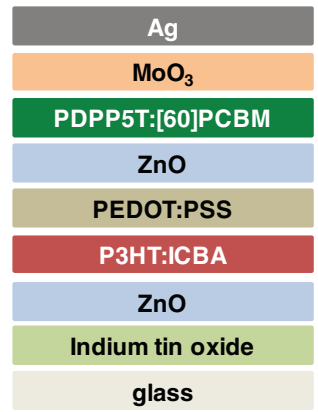

(b)
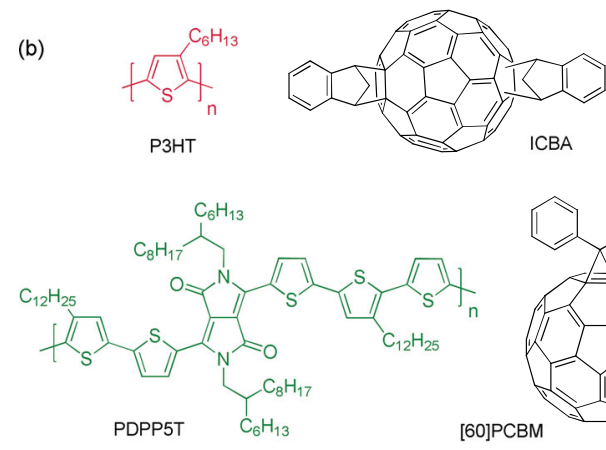

ICBA

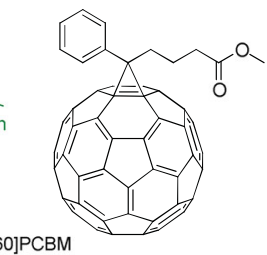

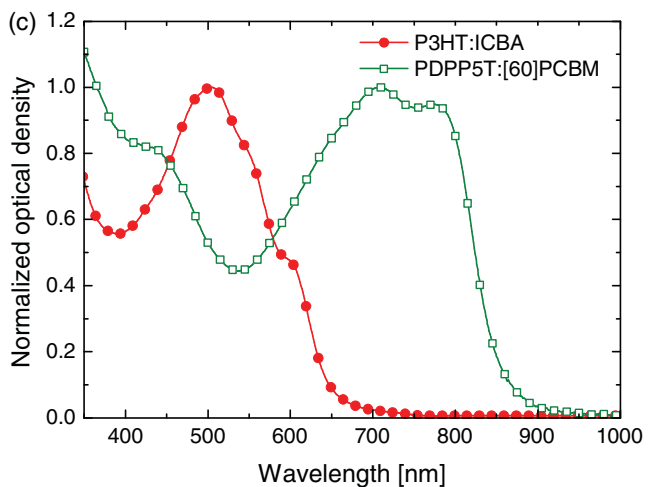

Figure 1. (a) Layout of the inverted tandem cell. (b) Structures of P3HT, ICBA, PDPP5T, and [60]PCBM used in the active layers. (c) Normalized absorption spectra of the P3HT:ICBA and PDPP5T:[60]PCBM active layers.

ITO electrode. For this purpose, we use a thermally annealed solution-processed $\mathrm{ZnO}$ nanoparticle layer as the electron collecting contact. ${ }^{[2]}$ Both P3HT:ICBA and PDPP5T:[60]PCBM can directly be deposited from solution onto this $\mathrm{ZnO}$ layer. Compared to normal configuration tandem cells, the challenge in making a solution-processed inverted cell is establishing a robust procedure for depositing a hole collecting layer on top of the first active layer. In principle, PEDOT:PSS is well suited for this purpose. However, PEDOT:PSS is generally processed as a dispersion in water and it is notoriously difficult to form a closed, thin $(<50 \mathrm{~nm})$, and smooth PEDOT:PSS layers on top of a polymer-fullerene layer by spin coating. Especially, for apolar and hydrophobic active layers, such as P3HT:ICBA, dewetting results in incomplete or poor film formation. This problem was effectively solved by using a combination of pretreating the P3HT:ICBA surface with a $\mathrm{N}_{2}$ plasma and using a PEDOT:PSS formulation designed for coating on plastic substrates. Specifically, we applied a mild $\mathrm{N}_{2}$ plasma $(0.6 \mathrm{mbar}, 10 \mathrm{~W}, 2 \mathrm{~s})$ to make the P3HT:ICBA surface more hydrophilic and then spin-coated PEDOT:PSS (Clevios F CPP105D diluted with isopropanol) to create a continuous $40 \mathrm{~nm}$ thin PEDOT:PSS film. The use of $\mathrm{N}_{2}$ as compared to air as plasma medium reduces the oxidation and deterioration of the photoactive P3HT:ICBA layer by the plasma. Using this procedure inverted single-junction ITO/ZnO/P3HT:ICBA/PEDOT:PSS/Ag devices were made reproducibly. Figure 2 shows the current density-voltage $(J-V)$ characteristics and external quantum efficiency (EQE) of the optimized P3HT:ICBA inverted cells with an active layer thickness

of $225 \mathrm{~nm}$. The short-circuit current density, determined from integrating the EQE with the solar spectrum $\left(J_{\mathrm{sc}}=8.27 \mathrm{~mA} \mathrm{~cm}{ }^{-2}\right)$, open-circuit voltage $\left(V_{\mathrm{oc}}=0.82 \mathrm{~V}\right)$, and fill factor $(\mathrm{FF}=0.65)$ result in a power conversion efficiency of $\eta=4.4 \%$ (Table 1 ) for this cell. The EQE reaches a maximum value of $67 \%$ at $530 \mathrm{~nm}$.

For the back cells, the processing is easier. The PDPP5T:[60]PCBM layer is more polar and the deposition of PEDOT:PSS from water/isopropanol does not require a plasma pretreatment. Besides a PEDOT:PSS/Ag top contact, we also tested $\mathrm{MoO}_{3} / \mathrm{Ag}$ as hole collecting electrode, obtaining identical results. The $J-V$ characteristics and EQE of the optimized inverted ITO/ZnO/PDPP5T:[60]PCBM/ $\mathrm{MoO}_{3} / \mathrm{Ag}$ single-junction cell with a $100 \mathrm{~nm}$ active layer are shown in Figure 2. The optimized cell gives $J_{\mathrm{sc}}=12.75 \mathrm{~mA} \mathrm{~cm}{ }^{-2}, V_{\text {oc }}=$ $0.59 \mathrm{~V}$, and $\mathrm{FF}=0.67$, resulting in a power conversion efficiency of $\eta=5.0 \%$ (Table 1 ).

Having established reproducible procedures for making efficient inverted singlejunction wide and small band gap cells, the construction of the tandem cell can be considered. In the tandem cell, we use a $\mathrm{ZnO}$ nanoparticle layer deposited from isopropanol on top of a PEDOT:PSS layer to create the intermediate recombination contact. UV-vis measurements verified that isopropanol does not wash away the previously deposited PEDOT:PSS layer. Acidic PEDOT:PSS solutions are known to readily dissolve $\mathrm{ZnO}$, but once the PEDOT:PSS layer has been thermally annealed the acidity does not cause a problem when $\mathrm{ZnO}$ nanoparticles are deposited on top. To test the performance of intermediate contact, ITO/PEDOT:PSS/ZnO/Ag devices were made. The $J-V$ characteristics (Figure 3 ) show that an ohmic PEDOT:PSS/ZnO contact is formed under UV illumination. The resistance measured is primarily determined by the series resistance of the ITO. UV illumination creates free electrons in the $\mathrm{ZnO}$ nanoparticles that help to establish a good contact with PEDOT:PSS. ${ }^{[23]}$ The effect of UV illumination saturates after 4 min (Figure 3), but we found that this time varies with different batches of $\mathrm{ZnO}$ nanoparticles prepared.

In tandem polymer solar cells with series connection, the layer thicknesses of the front and back cells have to be balanced to adjust the current extracted from each layer. We have previously shown that in polymer solar cells equalizing the current generation of the subcells is not a sufficient design criterion due to the significant dependence of the photocurrent on the applied voltage. ${ }^{[2]}$ To establish the optimal thickness of the photoactive layers in an inverted ITO/ZnO/P3HT:ICBA/PEDOT:PSS/Ag and ITO/ZnO/PDPP5T:[60]PCBM/ $\mathrm{MoO}_{3} / \mathrm{Ag}$ tandem configuration, we prepared the corresponding single-junction devices with a range of active layer thicknesses. For each layer thickness, we characterized the cells and also calculated the absorbed photon flux using a simulation of the optical absorption and reflection of the entire layer stack of the device using the wavelength 


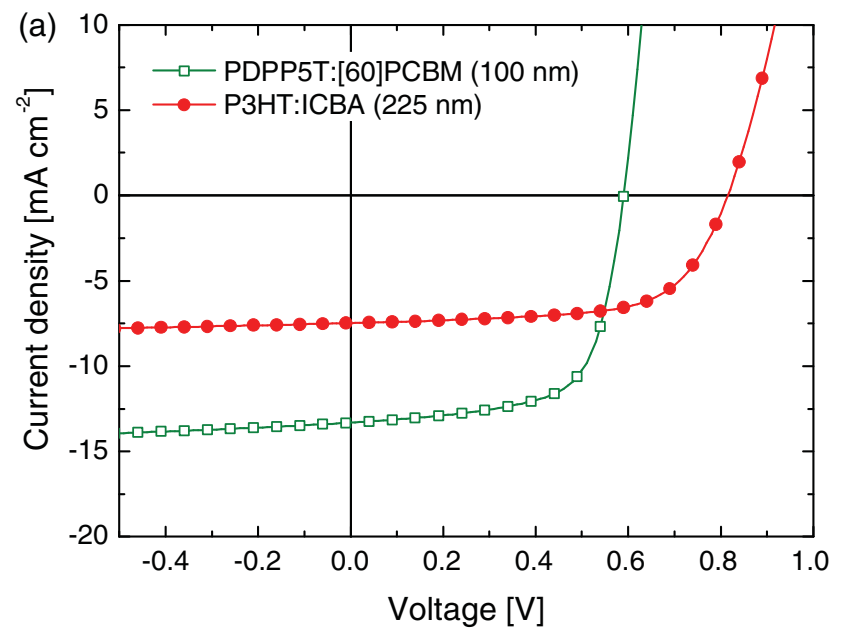

(b)
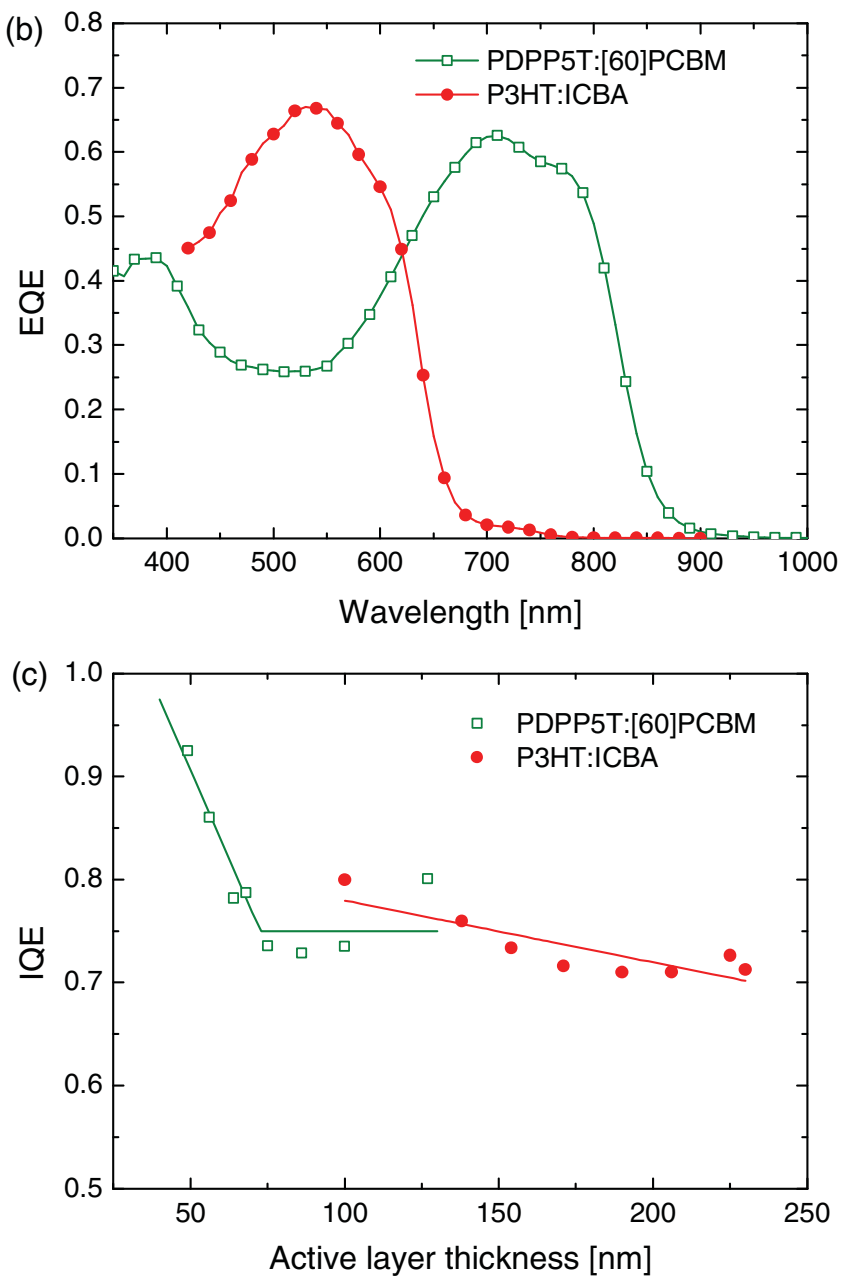

Figure 2. (a) $J-V$ curves of optimized single-junction inverted $\mathrm{ITO} / \mathrm{ZnO} /$ P3HT:ICBA/PEDOT:PSS/Ag and ITO/ZnO/PDPP5T:[60]PCBM/MoO $/$ $\mathrm{Ag}$ solar cells under simulated AM1.5G $\left(100 \mathrm{~mW} \mathrm{cm-}{ }^{2}\right)$ illumination. (b) EQEs of the same cells. (c) Spectrally averaged IQE versus layer thickness for P3HT:ICBA and PDPP5T:[60]PCBM inverted solar cells. The solid lines represent the values used for modeling.

dependent refractive index $(n)$ and extinction coefficient $(k)$ of the photoactive, charge transport, and electrode layers. The
Table 1. Characteristics of the optimized single-junction and tandem solar cells.

\begin{tabular}{lccccc}
\hline Active layer & $\begin{array}{c}J_{\mathrm{sc}^{2}}{ }^{2} \\
{\left[\mathrm{~mA} \mathrm{~cm}^{-2}\right]}\end{array}$ & $\begin{array}{c}J_{\mathrm{sc}}(\mathrm{EQE})^{\mathrm{b})} \\
{\left[\mathrm{mA} \mathrm{cm}^{-2}\right]}\end{array}$ & $\begin{array}{c}V_{\mathrm{oc}} \\
{[\mathrm{V}]}\end{array}$ & FF & $\begin{array}{c}\eta \\
{[\%]}\end{array}$ \\
\hline P3HT:ICBA $(225 \mathrm{~nm})$ & 7.48 & 8.27 & 0.82 & 0.65 & 4.4 \\
PDPP5T:[60]PCBM $(100 \mathrm{~nm})$ & 13.31 & 12.75 & 0.59 & 0.67 & 5.0 \\
Tandem measured & 7.23 & & 1.35 & 0.60 & 5.8 \\
\hline
\end{tabular}

a) Determined from white light $J-V$; b) Determined from integrating the EQE with the AM1.5 G spectrum.

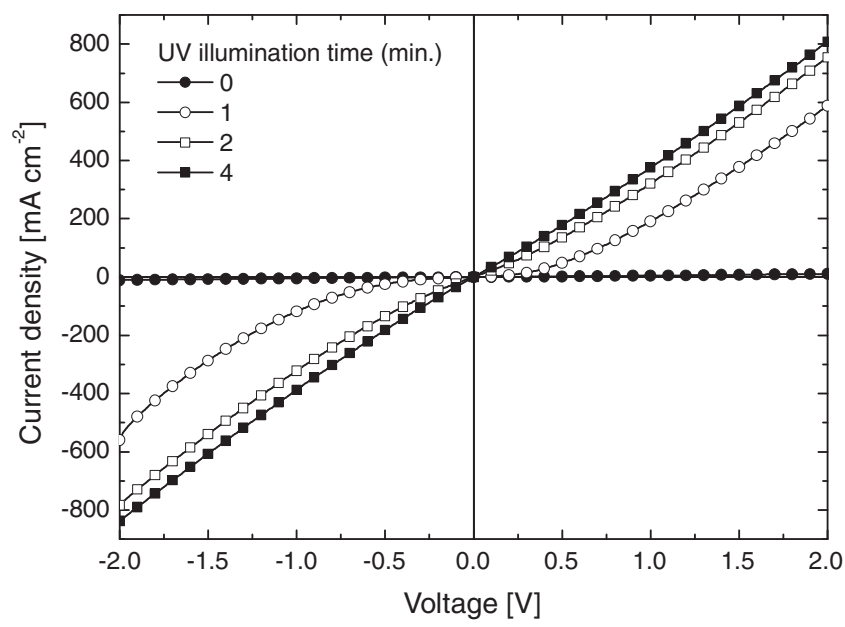

Figure 3. $J-V$ characteristic of an ITO/PEDOT:PSS/ZnO/Ag device, showing the effect of UV illumination on the recombination contact.

spectrally averaged internal quantum efficiency (IQE) was then determined as the ratio between the short-circuit current (obtained by integrating the product of the solar spectrum with the experimental EQE of the solar cell) and the absorbed flux of photons from the standard global air mass 1.5 sunlight (AM1.5G). Figure 2c shows that the spectrally averaged IQEs decrease with thickness but remain above $70 \%$ for both active layers. Combining the thickness dependent IQE and $J-V$ data with an optical simulation of the tandem cell configuration, we found that maximum performance for a ITO/ZnO/ P3HT:ICBA/PEDOT:PSS/ZnO/PDPP5T:[60]PCBM/ $\mathrm{MoO}_{3} /$ $\mathrm{Ag}$ tandem cell configuration is expected for layer thicknesses combinations ranging from 185 to $235 \mathrm{~nm}$ for the P3HT:ICBA front cell combined with 70-105 nm for the PDPP5T:[60]PCBM back cell.

Figure 4a shows the $J-V$ characteristics of a tandem cell with a $220 \mathrm{~nm}$ front cell and a $90 \mathrm{~nm}$ back cell after brief UV illumination to create the intermediate contact. The inverted tandem cell is characterized by $J_{\mathrm{sc}}=7.23 \mathrm{~mA} \mathrm{~cm}^{-2}, V_{\mathrm{oc}}=1.35 \mathrm{~V}$, and $\mathrm{FF}=0.60$ resulting in a power conversion efficiency of $\eta=5.8 \%$ (Table 1). Over 20 nominally identical devices the tandem cell efficiency was $5.5 \pm 0.4 \%$. The EQE of the inverted tandem cell (Figure $4 \mathrm{~b}$ ), measured under appropriate bias illumination and electrical bias conditions, ${ }^{[25]}$ shows that the subcells largely convert complementary parts of the solar spectrum with peak 


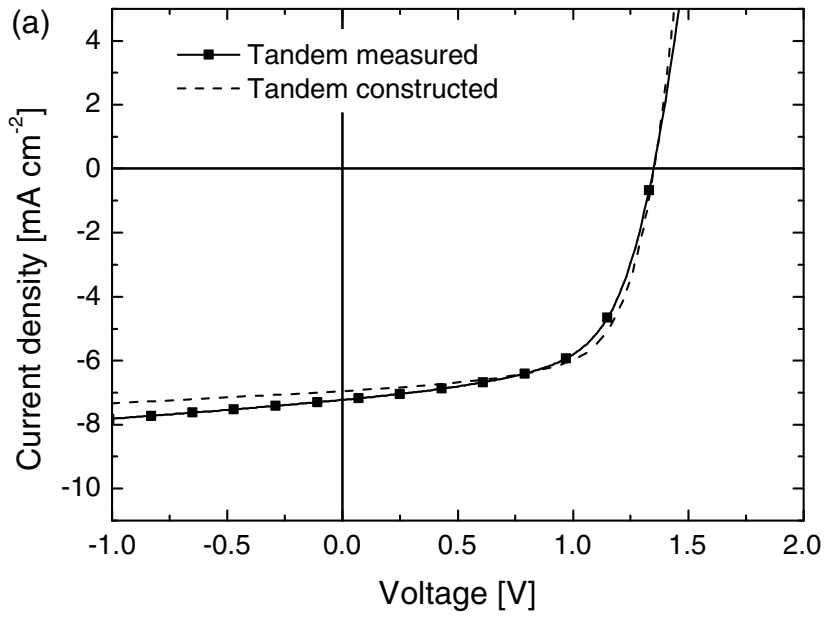

(b)
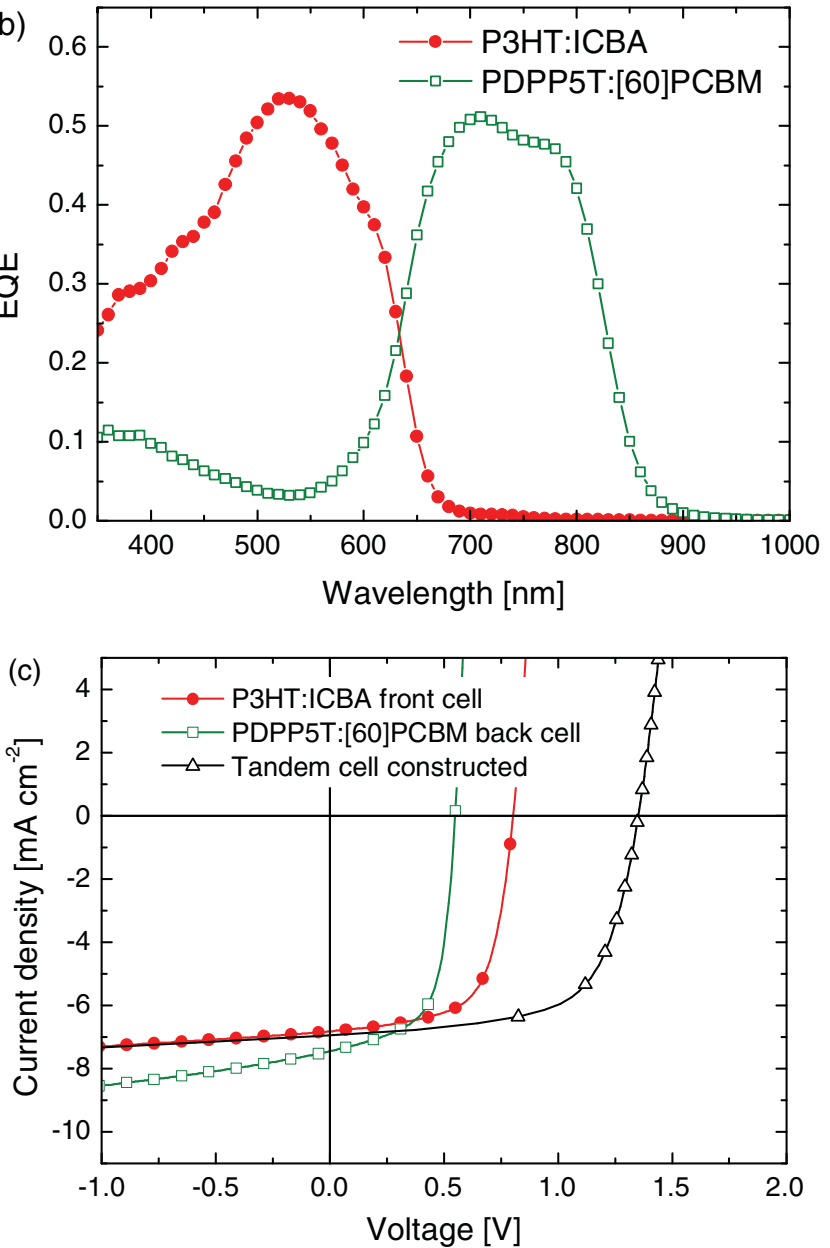

Figure 4. (a) Comparison of the $J-V$ characteristics of the measured and constructed tandem solar cell with a $220 \mathrm{~nm}$ P3HT:ICBA front cell and $90 \mathrm{~nm}$ PDPP5T:[60]PCBM back cell. (b) Experimental EQE of the same cell. (c) $J-V$ curves of single-junction reference cells measured under appropriate reduced light intensity and the constructed tandem.

EQEs over $50 \%$ in both cells. By integrating the two EQE

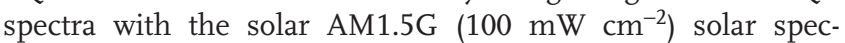
trum the short-circuit current densities of the subcells were
Table 2. Characteristics of the single-junction cells under reduced light intensity and of the constructed tandem cell.

\begin{tabular}{lcccc}
\hline Active layer & $\begin{array}{c}J_{\mathrm{sc}} \\
{\left[\mathrm{mA} \mathrm{cm}^{-2}\right]}\end{array}$ & $\begin{array}{c}V_{\mathrm{oc}} \\
{[\mathrm{V}]}\end{array}$ & FF & $\begin{array}{c}\eta \\
{[\%]}\end{array}$ \\
\hline P3HT:ICBA $(220 \mathrm{~nm})$ single junction ${ }^{\mathrm{a})}$ & 6.82 & 0.80 & 0.65 & - \\
PDPP5T:[60]PCBM $(90 \mathrm{~nm})$ single junction ${ }^{\mathrm{a})}$ & 7.45 & 0.55 & 0.63 & - \\
Tandem constructed & 6.98 & 1.35 & 0.64 & 6.1 \\
Tandem measured & 7.23 & 1.35 & 0.60 & 5.8 \\
\hline
\end{tabular}

a) Measured under reduced light intensity to provide the same $J_{\mathrm{sc}}$ as determined from integrating the EQE of the sub cell in the tandem cell with the AM1.5C spectrum (see text).

found to be $6.82 \mathrm{~mA} \mathrm{~cm}^{-2}$ for P3HT:ICBA and $7.45 \mathrm{~mA} \mathrm{~cm}^{-2}$ for PDPP5T:[60]PCBM. With these values it is possible to construct the $J-V$ characteristics of the tandem cell from the corresponding single-junction cells that were made on the same day as the tandem cells that have the same layer thickness as the subcells. The $J-V$ characteristics of the two single junctions (Figure 4c) were recorded under reduced illumination conditions, such that their short-circuit currents match with the values obtained from the EQEs of the subcells in the tandem. Assuming a loss-free recombination layer, the $J-V$ characteristic of the tandem can then be constructed (Figure 4c) by adding the two curves using Kirchhoff's law ${ }^{[26]}$ and compared to the measured characteristics (Figure 4a and Table 2). This comparison reveals that the PEDOT:PSS/ZnO recombination contact causes no loss in open-circuit voltage but that the fill factor in the tandem is reduced from the expected value of 0.64 to 0.60 . This is a small but significant loss that is at least partly caused by resistive losses as evidenced by the observation that the current density under forward bias in the constructed $J-V$ curve (which assumes zero resistance in the intermediate layer) exceeds the experimental values.

In conclusion, we have shown that a solution-processed recombination layer consisting of $40 \mathrm{~nm}$ of PEDOT:PSS and $30 \mathrm{~nm}$ of $\mathrm{ZnO}$ nanoparticles can be used to make efficient tandem solar cells with inverted polarity. By using a mild $\mathrm{N}_{2}$ plasma treatment and depositing PEDOT:PSS from water/ isopropanol, followed by spin-coating $\mathrm{ZnO}$ nanoparticles, we were able to reproducibly create a recombination contact onto hydrophobic P3HT:ICBA layers. The inverted tandem cell that comprises P3HT:ICBA as wide band gap front cell with high $V_{\text {oc }}$ and PDPP5T:[60]PCBM as small band gap back cell with lower $V_{\text {oc }}$. As a result, the tandem cell has a power conversion efficiency of $\eta=5.8 \%$, which is higher than that of the optimized single-junction cells and which is among the highest ones reported for this type of solar cells to date. Further advances in efficiency can be expected when polymer materials for more efficient single-junction layers become available and when the resistive losses in the recombination contact can be further reduced.

\section{Experimental Section}

Devices were fabricated by spin-casting $\mathrm{ZnO}$ nanoparticles from acetone onto precleaned indium tin oxide (ITO) substrates (Naranjo substrates), followed by annealing in a nitrogen-filled glove box at 
$150{ }^{\circ} \mathrm{C}$ for $15 \mathrm{~min}$. For PDPP5T single junctions, a 1:2 weight ratio of $6 \mathrm{mg} \mathrm{mL}^{-1}$ PDPP5T and [60]PCBM (Solenne BV) was dissolved in a $5 \% \mathrm{v} / \mathrm{v}$ solution of $o$-dichlorobenzene (ODCB) in chloroform and spin casted. The devices were completed by evaporation of $10 \mathrm{~nm}$ $\mathrm{MoO}_{3}$ and $100 \mathrm{~nm} \mathrm{Ag}$. For P3HT:ICBA single junctions and tandems, Plexcore PV2000 ink from Plextronics was spin casted on top of the $\mathrm{ZnO}$-covered ITO substrates and annealed for $30 \mathrm{~min}$ at $170^{\circ} \mathrm{C}$ in a nitrogen-filled glove box. A $\mathrm{N}_{2}$ plasma of $10 \mathrm{~W}$ was used for $2 \mathrm{~s}$ using a Diener Femto PCCE plasma reactor to make the active layer surface more hydrophilic. On top, Clevios F CPP105D PEDOT:PSS (Heraeus) diluted with $25 \% \mathrm{v} / \mathrm{v}$ of isopropanol was spin casted and annealed for $10 \mathrm{~min}$ at $120^{\circ} \mathrm{C}$. For single junctions, the device was completed by evaporation of $100 \mathrm{~nm} \mathrm{Ag}$. For tandem cells, a layer of $\mathrm{ZnO}$ nanoparticles was deposited from isopropanol and then annealed at $150{ }^{\circ} \mathrm{C}$ for $15 \mathrm{~min}$. To complete the tandem cell, PDPP5T:[60]PCBM from chloroform/ODCB was spin coated on top of the annealed $\mathrm{ZnO}$ layer, followed by deposition of $\mathrm{MoO}_{3}$ and $\mathrm{Ag}$ in high vacuum by thermal evaporation. Tandem cells were illuminated for several minutes with UV light with a Spectroline EN-160 L/F 365 nm hand lamp from Spectronics Corporation.

EQE measurements were performed in a homebuilt setup. Mechanically modulated (Stanford Research SR 540 chopper) monochromatic (Oriel, Cornerstone 130) light from a $50 \mathrm{~W}$ tungsten halogen lamp (Osram 64610) was used as probe light, in combination with continuous bias light from a solid state laser (B\&W Tek Inc. $532 \mathrm{~nm}, 30 \mathrm{~mW}$, and $780 \mathrm{~nm}, 21 \mathrm{~mW}$ ). The intensity of the bias laser light was adjusted using a variable neutral density filter. The response was recorded as the voltage over a $50 \Omega$ resistance, using a lock-in amplifier (Stanford Research Systems SR830). For the single-junction devices and the PDPP5T:[60]PCBM subcell, the measurement was carried out under representative illumination intensity (AM1.5C equivalent, provided by the $532 \mathrm{~nm}$ laser). For the P3HT:ICBA subcell, the measured EQE was mathematically corrected for the intensity difference between the monochromatic light and AM1.5G. For the tandem subcells, a compensating electrical bias was applied by the lock-in-amplifier to ensure short-circuit conditions in the respective subcells during the spectral response measurements.

Current density versus voltage $(U-V)$ curves were measured with a Keithley 2400 source meter under illumination with a tungsten-halogen lamp with a Schott GG385 UV filter and a Hoya LB120 daylight filter at $100 \mathrm{~mW} \mathrm{~cm}{ }^{-2}$ light intensity. The short-circuit density of the singlejunction solar cells was more accurately determined by convolution of the EQE with the AM1.5G solar spectrum.

For the tandem solar cell measurements, the mimicked solar light spectrum was tuned to provide appropriate illumination to both subcells. The $J-V$ curves of the tandem solar cell and P3HT:ICBA single junction were measured under illumination through a mask of smaller dimensions to the device area determined by the overlap of the ITO and Ag electrodes $\left(0.0676 \mathrm{~cm}^{2}\right.$ for the $0.09 \mathrm{~cm}^{2}$ cell and $0.1296 \mathrm{~cm}^{2}$ for the $0.16 \mathrm{~cm}^{2}$ cell), to avoid extra current generation due to the high lateral conductivity of the PEDOT:PSS

Layer thicknesses were measured using a Veeco Dektak 150 Surface Profiler. The absorption of the active layers was determined by spin casting on glass and measuring with a Perkin-Elmer Lambda 900 UV-vis spectrometer.

Calculations of the optical electric field were performed with Setfos 3 (Fluxim AG, Switzerland). The other optical constants were obtained from literature. ${ }^{[21,23,27-29]}$

\section{Acknowledgements}

The research was supported by Agentschap NL in the POLYMOL project APOLLO (ERAPV01005). This work forms part of the Joint Solar Programme (JSP) and of the Stichting voor Fundamenteel Onderzoek der Materie (FOM), which is supported financially by Nederlandse
Organisatie voor Wetenschappelijk Onderzoek (NWO). This work is cofinanced by Nuon Heliantos.

Received: December 21, 2011

Published online:

[1] For a recent review see: P. T. Boudreault, A. Najari, M. Leclerc, Chem. Mater. 2011, 23, 456.

[2] R. F. Service, Science 2011, 332, 293.

[3] M. A. Green, K. Emery, Y. Hishikawa, W. Warta, Prog. Photovolt. Res. Appl. 2011, 19, 84.

[4] A. Hadipour, B. de Boer, J. Wildeman, F. B. Kooistra, J. C. Hummelen, M. G. R. Turbiez, M. M. Wienk, R. A. J. Janssen, P. W. M. Blom, Adv. Funct. Mater. 2006, 16, 1897.

[5] J. Gilot, M. M. Wienk, R. A. J. Janssen, Appl. Phys. Lett. 2007, 90 143512.

[6] J. Y. Kim, K. Lee, N. E. Coates, D. Moses, T.-Q. Nguyen, M. Dante, A. J. Heeger, Science 2007, 317, 222.

[7] T. Ameri, G. Dennler, C. Lungenschmied, C. J. Brabec, Energy Environ. Sci. 2009, 2, 347.

[8] S. Sista, M.-H. Park, Z. Hong, Y. Wu, J. Hou, W. L. Kwan, G. Li, Y. Yang, Adv. Mater. 2009, 22, 380.

[9] J. Gilot, M. M. Wienk, R. A. J. Janssen, Adv. Mater. 2010, 22, E67.

[10] M. White, D. Olson, S. Shaheen, N. Kopidakis, D. Ginley, Appl. Phys. Lett. 2006, 89, 143517.

[11] C. Waldauf, M. Morana, P. Denk, P. Schilinsky, K. Coakley, S. Choulis, C. Brabec, Appl. Phys. Lett. 2006, 89, 233517.

[12] K. Norrman, M. V. Madsen, S. A. Gevorgyan, K. C. Krebs, J. Am. Chem. Soc. 2010, 132, 16883.

[13] M. T. Lloyd, C. H. Peters, A. Garcia, I. V. Kauvar, J. J. Berrya M. O. Reese, M. D. McGehee, D. S. Ginley, D. C. Olson, Sol. Energy Mater. Sol. Cells 2011, 95, 1382.

[14] D. W. Zhao, L. Ke, Y. Li, S. T. Tan, A. K. K. Kyaw, H. V. Demir X. W. Sun, D. L. Carroll, G. Q. Lo, D. L. Kwong, Sol. Energy Mater. Sol. Cells 2011, 95, 921.

[15] X. W. Sun, D. W. Zhao, L. Ke, A. K. K. Kyaw, G. Q. Lo, D. L. Kwong, Appl. Phys. Lett. 2010, 97, 053303.

[16] C.-H. Chou, W. L. Kwan, Z. Hong, L.-M. Chen, Y. Yang, Adv. Mater. 2011, 23, 1282

[17] S. K. Hau, H.-L. Yip, K.-S. Chen, J. Zou, A. K.-Y. Jen, Appl. Phys. Lett. 2010, 97, 253307

[18] T. T. Larsen-Olsen, E. Bundgaard, K. O. Sylvester-Hvid, F. C. Krebs, Org. Electron. 2011, 12, 364

[19] D. W. Laird, R. Stegamat, H. Richter, V. Vejins, L. Scott, T. A. Lada, Patent Application WO 2008/018931.

[20] G. Zhao, Y. He, Y. Li, Adv. Mater. 2010, 22, 4355.

[21] V. S. Gevaerts, A. Furlan, M. M. Wienk, M. Turbiez, R. A. J. Janssen, Adv. Mater. 2012, DOI: 10.1002/adma.201104939.

[22] S. K. Hau, H.-L. Yip, N. S. Baek, J. Zou, K. O’Malley, A. K.-Y. Jen, Appl. Phys. Lett. 2008, 92, 253301.

[23] G. Lakhwani, R. Roijmans, A. J. Kronemeijer, J. Gilot, R. A. J. Janssen, S. C. J. Meskers, J. Phys. Chem. 2010, 114, 14804

[24] J. Gilot, M. M. Wienk, R. A. J. Janssen, Adv. Mater. 2010, 22, E67.

[25] J. Gilot, M. M. Wienk, R. A. J. Janssen, Adv. Funct. Mater. 2010, 20, 3904.

[26] A. Hadipour, B. de Boer, P. W. M. Blom, Org. Electron. 2008, 9, 617.

[27] E. D. Palik, G. Ghosh, Handbook of Optical Constants of Solids, Academic Press, Boston, USA 1998.

[28] L. A. A. Pettersson, S. Ghosh, O. Inganäs, Org. Electron. 2002, 3, 143

[29] J. Gilot, I. Barbu, M. M. Wienk, R. A. J. Janssen, Appl. Phys. Lett. 2007, 91, 113520 